\title{
SYNTACTIC AND SEMANTIC ACCESS IN GERMAN: AN ON-LINE PSYCHOLINGUISTIC EXPERIMENT WITH THE VERB HABEN
}

Acesso sintático e semântico em alemão: um experimento psicolingüístico on-line com o verbo haben

\section{Aleria Cavalcante Lage*}

\section{Introduction}

$\mathrm{H}$ ow do the syntactic modules function? How can we empirically find biological evidence to the linguistic universals? What strategies are These are some of the most intriguing questions of contemporary linguistics. And, in fact, some of these puzzles have started to be deciphered theoretically in the latest versions of the Generative Grammar (Chomsky, 1995; 1999; 2001).

Besides the exciting theoretical framework, there is a variety of processing models that evaluate the language faculty as to its psychological reality. One of the most tested psycholinguistic models is the Minimal Attachment, fully explained in Construal (Frezier; Clifton Jr., 1996). It previews that, in face of

* Doutoranda do Programa de Pós-graduação em Linguística da UFRJ. 
an on-line linguistic input, in order to fulfill the demanding task of immediate decoding, we use a unique, serial cognitive strategy that attempts at establishing an immediate Primary Syntactic Relation between the verb and its complement, structuring the minimally necessary phrase marker. This essential strategy of verb-complement merge is the Minimal Attachment (hence MA).

Since the MA is a serial model, its strategy amounts to the formation of only one structure. The moment a segment is taken as a verb and the subsequent segment as its complement, we bet on a propositional closure right after the complement. If, in the course of the derivation, a new element comes up that needs to be integrated, it might not fit in the structure previewed by the MA. If this is the case, the model purports that there will be moment of surprise and hesitation in the processing: the Garden path Effect. After that, the prediction is that the derivation restarts through the reanalysis of the already-integrated input. If possible, there will be a derivation repair, which will require more than the minimal resources previously used to make the prediction that turned out being wrong. These new resources might include a new derivation, operations executed on the Logical Form or even access to discourse principles. Let us analyze (1) under the light of the Construal model:

(1) The teacher believed the student was in the park.

According to the MA predictions, the verb believed will look for its complement in order to merge with it immediately. The student is an excellent candidate. However, due to a characteristic of English, which allows us to omit the conjunction that, a noun may occasionally look as if it were the object of a verb, and only the succeeding words make it clear that instead, the noun is really the subject of a that-less subordinate clause that followed.

Having come across the rest of the sentence after the student, the speaker experiences a processing halt in which the Garden path Effect takes place in order to reinterpret the noun the student as the subject of the that-less subordinate clause. Consequently, the student was in the park will be selected by believed as its complement, which, in this case, will not be minimal, but clausal.

Psycholinguistics creates protocols that can indirectly assess processing in each of its phases, through the measurements of reaction time and performance rate in grammaticality judgment tests. For instance, we could set up an experiment in which volunteers would read segments of (1) on the computer screen, one after the other: 
LAGE, A. C. Syntactic and semantic access in German...

\begin{tabular}{c|c|c|c}
\hline SEGMENT 1 & SEGMENT 2 & SEGMENT 3 & SEGMENT 4 \\
\hline The teacher & believed & the student & was in the park \\
\hline
\end{tabular}

After the processing of each segment, the volunteer should press the space bar in order to see the next segment on the screen. The underlying computer protocol that is commanding the display of the stimuli is also in charge of recording all the reaction times of the volunteer to each segment and also his assessment of the grammaticality of the sentence. These data (reaction times of each segment and assessment of the grammaticality of sentences) are automatically inscribed in a $\log$ file that can be accessed by the experimenter at the end of the test. In our example-sentence, the reaction time relative to was in the park in (1) would be longer than the reaction time after the same segment inserted in another sentence as in (2):

(2) The student was in the park with the teacher and other students

\begin{tabular}{c|c|c|c}
\hline SEGMENT 1 & SEGMENT 2 & SEGMENT 3 & SEGMENT 4 \\
\hline The teacher & was in the park & with the teacher & and other students \\
\hline
\end{tabular}

This would happen because the prevision made after was in the park in (2) turned out being successful. Indeed, it was worth having bet on the minimal assumption here. Differently from (1), the processing time prior to the reaction time in relation to was in the park in (2) did not include time spent with uncertainty or with the necessity to repair the minimal assumptions previously made.

This paper, Syntactic and semantic access in German: an on-line psycholinguistic experiment with the verb 'haben', intends to verify not only the relations that were previously exemplified, but also the strategy adopted in order to merge the subject NP (external argument) to an element in the derivation. The interesting feature of this merge is that, although the subject is pronounced before the verb and the complement, it should be merged after, since verbcomplement is the very first merge operation that takes place in sentence processing (Chomsky, 1995; Frazier; Clifton Jr., 1996). This assumption logically implies in the belief that sentence processing is a bottom-up operation and that 
the processing of subject is first a mnemonic operation followed by the verbcomplement merge and finally by the subject integration.

Thus, in order to try to access the psychological reality of the bottom-up course of the derivation, I developed three psycholinguistics tests' in German, whose peculiar word order facilitates the investigation of subtle aspects of sentence processing as it can be appreciated as follows. The default word order in declarative sentences in German is S-V-O:

(3)

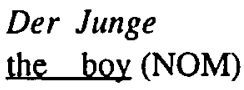

hat

has einen Saft

a juice (ACU)

Nevertheless, in certain structural conditions, like that of compound tenses with haben (have) as an auxiliary verb, the word order is S-Aux-OParticiple:

(4)
Die Frau
hat
einen Wagen
gekauft
the woman (NOM)
[Aux Perfekt]
$\underline{\text { a }} \quad \operatorname{car}(\mathrm{ACU})$
bought

According to Construal, economy conditions force the processing mechanism, at an initial moment, to try to integrate the linguistic input the simplest way. The verb is merged to its complement without taking into account a semantic seletional criterion: Minimal Attachment (MA). MA postulates a strictly syntactic merge, without any semantic access (Frazier; Clifton Jr., 1996).

So in (4), according to MA, as soon as the input hat (has) is internalized, it is interpreted as the main verb; and einen Wagen (a car), as its internal argument. Thus, when gekauft (bought) appears, there is an impasse, the Garden path Effect, which is followed by a derivational reanalysis. During the reanalysis, the simplest prevision, that would interpret hat as a finite verb, would have to be reformulated, to accommodate the reading of auxiliary verb to hat and of main verb to gekauft. The fact that the MA was not successful in (4) would be a nonoptimal condition inherent to German in this type of syntactic configuration (SAux-O-Participle).

1 This study was applied as a pilot to the main neurolinguistics experiment in my PhD Thesis. This main experiment involves the extraction of event related brain potentials (ERPs) and is being performed at CLIPSEN, the Federal University of Rio de Janeiro Laboratory Linguistics Merges: Psycholinguistics and Neurophisiology, located at the Linguistics Department of the UFRJ and under the coordination of Professor Miriam Lemle, associated with the Biological Signal Processing Laboratory of the Graduate Program in Biomedical Engineering (COPPE/ UFRJ), coordinated by Professor Antonio Fernando Catelli Infantosi. 
With the objective of investigating this minimality question, this study intends to create experimental circumstances in which the early semantic access of the internal and external argument, if any of the two occurs, would provoke an increase of the reaction time to segments, which would be detected through the used protocol.

\section{The experiment}

\section{Metodology}

I created a self-paced reading experiment, whose script was developed in Presentation 0.5 (produced by Neurobehavioral Systems, Albany, USA). It is one of the several stimulus presentation software that compile written or audio stimuli scripts designed for cognitive experiments.

Two hundred sentences in German (120 stimuli and 80 distractors) were presented, in pseudo-random order, to 16 monolingual German speakers (nine men) from Germany. Such volunteers were temporarily in Rio de Janeiro. They were either engineers on repair missions to the Angra dos Reis power plants, itinerary officials, working at the German Consulate in Rio, and German tourists visiting German residents in Rio. Subjects belonged to the 18-53 year old age bracket (average of 37,3 years old) and were college graduates or students.

About the stimuli preparation, the following aspects were observed: (i) I determined a reasonable sentence size, containing four or three segments; (ii) a fixed word class pattern was followed: determiner + noun + auxiliary + determiner + noun (+ past participle); (iii) the NPs, the verbs and the past participles were not repeated; (iv) the segment sizes were almost identical, with a maximal variation of two syllables; ( $v$ ) the used NPs, verbs and participles had a few syllables, and the composed words were avoided, although not abolished, so that a natural feature of the German language was not lost; (vi) I selected only simple semantics and frequently used words (except for NPs that referred to 'things that nobody can have', which were naturally less common words).

The distractors had the same number of segments as the stimuli (three or four), but the word size was different from those in the stimuli, though there were no discrepancies, considering the features of the experimental sentences as a whole. Thus, the distractors had the same size of the test sentences, but presented other syntactic structures. 
To do the test, the volunteers sat down in front of a laptop screen and first read the instructions. They were then submitted to a warm-up phase. The experiment itself began when the volunteers thought they had understood the task perfectly.

The instructions, as well as the warm-up and test sentences, were presented in white font, of Times New Roman type and size 15, on a 15 inch black screen, with $1024 \times 768$ resolution. After reading the instructions, the volunteers hat to press the space bar to begin the warm-up and then the experiment. When they were ready to begin the test, they pressed the space bar, and the first phrasal segment appeared immediately on the screen, which was always the subject (Determiner + NP). In relation to the distractors, the first constituent might be the subject of the sentence or not, varying among a WH- word, a verb, an adjunct, etc. After finishing processing the first segment, the volunteers pressed the space bar again so that another segment appeared. This operation was repeated until the last sentence segment. The segments were NP, V and NP or NP, Aux, NP and Participle.

After the last segment of each sentence, an interpretative question would come up. The volunteer had to press the key ja (yes) or nein (no) to go on with the experiment. As soon as the key was pressed, a fixation cross appeared for $2000 \mathrm{~ms}$ on the screen immediately before the first segment of the next stimulus or distractor. This cross was used to induce the subject to fix his look at the center of the screen and to neutralize any semantic influence from the previous sentence. In case the volunteer exceeded $2000 \mathrm{~ms}$ to press a key, the wait-foranswer mode of the experiment would time-out and the first segment of the next sentence would appear automatically on the screen.

The experimental sentences were of the types (3), S-V-O, and (4), S-AuxO-Participle. The sentences of type (3) were introduced as a control group, so that volunteers would not always expect to have the participial form after the object, as in the target sentences (4).

(3)

Der Junge
the boy (NOM)

(4) Die Frau the woman (NOM) hat

has

hat

[aux Perfekt] einen Saft

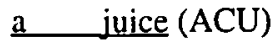

einen Wagen

$\underline{a}$ car (ACU) gekauft bought

Since the sentences in this experiment were elaborated to test the several conditions, their exact composition will be described, test by test. At this point, I 
have to say that I worked with three 'levels of semantic plausibility' for the internal arguments of haben (have), as main verb, and three levels for the external ones. I used a subjective criterion to classify the arguments into these semantic plausibility levels, carefully following pre-established parameters: a plausible or possible situation (the boy has a book), a more or less plausible or improbable situation (the boy has a lake) and an implausible or impossible situation (the boy has the moon).

I used a same number of experimental sentences with final participial forms in each one of the three 'levels of semantic plausibility' of the internal argument - sentences (a), (b) and (c); in each one of the three 'levels of semantic plausibility' of the external argument - sentences (d), (e) and (f); besides a same number of experimental sentences without participles and with finite verbs different from haben, in which an excellent 'level of semantic plausibility' of the internal and external arguments was kept - these became the experimental control group, sentences $(\mathrm{g}),(\mathrm{h})$ and (i).

SERIES 1 - Level of semantic plausibility of the internal argument of haben

(a) Der Junge hat einen Saft getrunken

(+plausible object for haben) (the boy has a juice drunk)

(b) Der Junge hat einen See gesehen (the boy has a lake seen)

(土plausible object for haben)

(c) Der Junge hat einen Mond gezeichnet (the boy has a moon drawn)

(-plausible object for haben)

SERIES 2 - Level of semantic plausibility of the external argument

(d) Der Junge hat einen Saft getrunken

(+plausible subject) (the boy has a juice drunk)

(e) Die Ameise hat einen Saft getrunken (the ant has a juice drunk)

(f) Der Stuhl hat einen Saft getrunken (the chair has a juice drunk)

(土plausible subject)

(-plausible subject) 
SERIES 3 - Control group: excellent level of semantic plausibility of the internal and external arguments of transitive verb in finite tense

(g) Der Junge trinkt einen Saft (the boy drinks a juice)]

(+plausible subject and object)

(h) Der Junge sieht einen See (the boy sees a lake)

(+plausible subject and object)

(i) Der Junge zeichnet einen Mond (the boy draws a moon)

(+plausible subject and object)

Test 1: Verification of the Minimal Attachment and the Garden path Effect Hypotheses

The first test had the objective of verifying the findings of Frazier and Clifton Jr. (1996), that the Minimal Attachment is the basic strategy of sentence processing. If their predictions really applied, in German, the auxiliary haben (have) in sentences with verb-final structure would first be interpreted as main verb, as we can see in (5).

(5) Der Junge the boy (NOM) has

Minimal Attachment strategy:

Until here, hat is interpreted as main verb.

Also according to this theory, by receiving the input getrunken (drunk), the speaker would enter into Garden path, that is, would hesitate in front of the previously postulated derivation. If it is true, after this short hesitation, he would start reformulating his initial analysis of haben as main verb and would then classify him as auxiliary verb (of the German verbal tense Perfekt), repairing the initial syntactic relations and the sentence meaning, in which the direct object is the complement of the participial form. 


\section{Reanalysis:}

(5)

$\begin{array}{lll}\text { Der Junge } & \text { hat } & \text { einen Saft getrunken } \\ \text { the boy (NOM) } & \text { [aux Perfekt] a juice (ACU) drunk }\end{array}$

At this point, hat is reinterpreted as auxiliary verb

To verify this condition, I measured the reaction time to haben (A) in every sentence and compared it with the reaction time of all other finite verbs (B). The reaction time to haben (A) and those of the other finite verbs (B) were also compared to the reaction time of the participles in sentences with +plausible, \pm plausible and -plausible complement for haben, respectively (C), (D) and (E). In the following table, we find the types of tested sentences, the segments whose reaction times were measured (those with letters between parentheses) and the comparisons that were done.

TABLE 1 - SENTENCE MODELS IN WHICH THE REACTION TIME TO IIABEN WAS COMPARED TO THAT OF THE OTHER FINITE VERBS, AND THE REACTION TIME OF ALL FINITE VERBS (INCLUDING THAT OF HABEN) WAS COMPARED TO THE REACTION TIME OF THE PARTICIPLES

\begin{tabular}{|c|c|c|c|c|}
\hline \multirow{6}{*}{$\begin{array}{l}\text { sentence } \\
\text { segments }\end{array}$} & Der Junge & hat (A) & einen Saft & getrunken $(C)$ \\
\hline & Der Junge & hat $(\mathrm{A})$ & einen See & gesehen (D) \\
\hline & Der Junge & hat (A) & einen Mond & gezeichnet (E) \\
\hline & Der Junge & trinkt $(\mathrm{A})$ & einen Saft & \\
\hline & Der Junge & $\operatorname{sieht}(A)$ & einen See & \\
\hline & Der Junge & zeichnet (A) & einen Mond & \\
\hline
\end{tabular}

Comparisons:

Average of (A) compared to the average of (B). I wanted to know if hat (has) was really being considered as the main verb. If this were true, the reaction time to it would be similar to that of full content verbs such as trinkt (drinks), sieht (sees) and zeichnet (draws). 
Average of (A) and (B) compared to the average of (C), (D) and (E). The objective of this comparison was to verify if the reaction time of each group of verbs in the past participle - getrunken (drunk), gesehen (seen) e gezeichnet (drawn) - was longer than the reaction time to haben (A) and to the other finite verbs (B), since the reanalysis and the repair are supposedly required to reintegrate the direct objects appropriately.

\section{Test 2: Verification of the semantic plausibility effect of the internal argument}

To verify if the factor semantic plausibility of the object affected the sentence processing, the reaction time to the participles was compared in the three levels of semantic plausibility for the complement of haben: +plausible, \pm plausible and -plausible. To increase the precision of the results, the comparison was done in twos. The following table shows the tested sentence types, the segments whose reaction times were measured and the comparison results.

TABLE 2 - SENTENCE MODELS WITH VARIATION OF THE SEMANTIC PLAUSIBILITY LEVEL OF THE INTERNAL ARGUMENT. THE AVERAGES OF THE REACTION TIMES TO THE INTERNAL ARGUMENTS WERE COMPARED AMONG THEMSELVES, AND THOSE OF THE PARTICIPLES TOO

\begin{tabular}{|c|c|c|c|c|}
\hline \multirow{2}{*}{$\begin{array}{c}\text { sentence } \\
\text { segments }\end{array}$} & Der Junge & hat & eimen Saft (F) & getrunken (C) \\
\cline { 2 - 5 } & Der Junge & hat & einen See (G) & gesehen (D) \\
\cline { 2 - 5 } & Der Junge & hat & einen Mond (H) & gezeichnet (E) \\
\hline
\end{tabular}

Comparisons:

Average of $(F)$ compared to the average of $(G)$. This comparison object was to detect if, during the merge with haben, the reaction time to the \pm plausible complements (G) - example, See (lake) - was longer if compared to the time of the +plausible complements (F) - of the type Saft (juice). 
Average of (F) compared to the average of $(\mathbf{H})$. I also wanted to know if, during the merge with haben, the reaction time of the -plausible complements (H) - like Mond (moon) - was longer than the time of the +plausible ones (F) Saft.

Average of $(\mathbf{G})$ compared to the average of $(\mathbf{H})$. I verified if, at the moment of the merge with haben, the reaction time of the -plausible complements $(\mathbf{H})$ Mond - was longer than the time of the \pm plausible ones $(G)-S e e$.

Average of (C) compared to the average of $(D)$, average of $(C)$ compared to the average of $(E)$ and average of $(D)$ compared to the average of $(E)$. These three comparisons function as the control group for the 'semantic plausibility factor' of the internal argument. The entry of the participles at this point of the derivation converge the three levels into +plausible, because the used participles match semantically with the complements (drank a juice, saw a lake, drew a moon). Therefore, the expectancy here was that, with the three semantic plausibility levels of complement converged into only one, the reaction time would be the same to every participle.

Test 3: Verification of the semantic plausibility effect of the external argument

To verify if the factor 'semantic plausibility of the subject' affected the sentence processing, the reaction time to the participles was compared on the three subject levels: +plausible, \pm plausible and -plausible.

TABLE 3 - SENTENCE MODELS WITH VARIATION OF THE SEMANTIC PLAUSIBILITY LEVEL OF THE EXTERNAL ARGUMENT. THE AVERAGES OF THE REACTION TIMES TO THE PARTICIPLES WERE COMPARED AMONG THEMSELVES

\begin{tabular}{|c|c|c|c|c|}
\hline \multirow{4}{*}{$\begin{array}{c}\text { sentence } \\
\text { segments }\end{array}$} & Der Junge & hat & einen Saft & getrunken (I) \\
\cline { 2 - 5 } & Der Ameise & hat & einen Saft & getrunken (J) \\
\cline { 2 - 5 } & Der Stuhl & hat & einen Saft & getrunken (K) \\
\hline
\end{tabular}


LAGE, A. C. Syntactic and semantic access in German...

\section{Comparisons:}

Average of (I) compared to the average of (J). The external argument processing was also evaluated through the reaction time in relation to the participial form. In this series, the subjects were the only sentence segments that were manipulated by the 'semantic plausibility' factor. So, if there were an increase in the reaction time to participle this would suggest that some semantic access to the external argument took place after the verb-object merge. At that moment, the speaker would reanalyze the verb-complement unit and would merge the subject, kept initially in the memory.

In sentences of this type, the subject was manipulated in three levels of semantic plausibility. Thus, the average of (I) was compared to the average of $(J)$, so that we could know if the reaction time to the participles of the type (J), which appear in sentences with a \pm plausible subject, like Ameise (ant), was really longer than the reaction time to the participles of the type (I), in sentences with a +plausible subject, for example, Junge (boy).

Average of $(\mathrm{I})$ compared to the average of $(\mathrm{K})$. Following the same previous reasoning that the reaction time to the participle would be different in this sentence series with variation of the semantic plausibility level of the subject, the average of (I) was compared to the one of $(\mathrm{K})$. The intention was to investigate if the reaction time of the participles of the type $(K)$, in the sentences with -plausible subject, for example, Stuhl (chair), was also longer than the reaction time to the participles of the type (I), in the sentences with +plausible subject (Junge).

Average of $(\mathbf{J})$ compared to the average of $(\mathbf{K})$. The third comparison of this kind was among the averages of the participial forms following the models $(\mathrm{J})$ and $(\mathrm{K})$, with the objective of checking if the reaction time to the participles of the type (K), in the sentences with -plausible subject (Stuhl), was longer than the reaction time to the participles of the type $(J)$, in the sentences with \pm plausible subject (Ameise). 


\section{Results}

Test 1: Comparison of the reaction time to haben to that to the other finite verbs - Minimal Attachment Hypothesis

TABLE 4 - SENTENCE MODELS IN WHICH THE SAMPLES OF HABEN WERE STATISTICALLY COMPARED TO THOSE OF THE OTHER FINITE VERBS

\begin{tabular}{|c|c|c|c|c|}
\hline \multirow{6}{*}{$\begin{array}{l}\text { sentence } \\
\text { segments }\end{array}$} & Der Junge & hat (A) & einen Saft & getrunken \\
\hline & Der Junge & hat $(\mathrm{A})$ & einen See & gesehen \\
\hline & Der Junge & hat (A) & einen Mond & gezeichnet \\
\hline & Der Junge & trinkt (B) & einen Saft & \\
\hline & Der Junge & sieht (B) & einen See & \\
\hline & Der Junge & zeichnet (B) & einen Mond & \\
\hline
\end{tabular}

The lexical finite verbs (B) resulted in an average of $610 \mathrm{~ms}$, and the average of haben (A) was $586 \mathrm{~ms}$. To find the statistical significance of this and other results, that will still come, I used the Analysis of Variance (ANOVA), of the Matlab $b^{\otimes}$ package, version 5.2 (produced by The MathWorks, Inc., Massachusetts, USA), which is a software turned to research that performs, among many other applications, most statistical variance analysis. This analysis finds a value of ' $p$ ' that must equal or be smaller than 0,05 . This comparison originated a $\mathbf{p}=\mathbf{0 , 1 0}$. Therefore, the difference among the compared samples is not statistically significant, i. e., they are equal in statistical terms. 
LAGE, A. C. Syntactic and semantic access in German...

TABLE 5 - SAMPLES OF (A) COMPARED TO THOSE OF (B): $\mathbf{P}=\mathbf{0 , 1 0}$

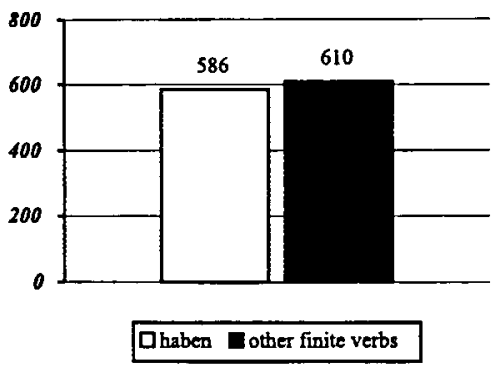

Discussion:

The reaction time to haben was statistically the same as to those to other verbs. This seems to indicate that verbs with similar number of syllables and frequency of use require practically the same time of processing, no matter if there is a semantically empty verb, like haben, among them.

In fact, according to the Minimal Attachment Hypothesis, there would be no sense for haben to cause a longer reaction time than those to the other verbs, if an optimist prediction for the minimum was first established. According to this prediction, the volunteer would first face haben as a main verb that searches for its complement with which to form a phrase marker (verbcomplement). Thus, this result proves the Minimal Attachment Hypothesis.

\section{Continuation of Test 1: Comparison of the reaction time of haben to that of the participles - Garden path Effect}

TABLE 6 - SENTENCE MODELS IN WHICH THE SAMPLES OF HABEN WERE STATISTICALLY COMPARED TO THOSE OF THE PARTICIPLES

\begin{tabular}{|c|c|c|c|c|}
\hline \multirow{6}{*}{$\begin{array}{l}\text { sentence } \\
\text { segments }\end{array}$} & Der Junge & hat (A) & einen Saft & getrunken (C) \\
\hline & Der Junge & hat (A) & eiren See & gesehen (D) \\
\hline & Der Junge & hat (A) & eizen Mond & gezeichuet (E) \\
\hline & Der Junge & प्रांkt (B) & einen Saft & \\
\hline & Der Junge & sieht (B) & einen See & \\
\hline & Der Junge & zeichret (B) & eiren Mond & \\
\hline
\end{tabular}


The reaction times to haben (A) and to the other finite verbs (B) had an average of $598 \mathrm{~ms}$; and the reaction times to the participial forms of the three groups - (C), (D) and (E), 772 ms. After the statistical treatment of these data, I verified that the difference between these averages had really a relevance, since $\mathbf{p}=\mathbf{0 , 0 0}$; that is, average of the reaction time to the participles was, in fact, bigger than that to the finite verbs.

TABLE 7 - SAMPLES OF (A) AND (B) COMPARED TO THOSE OF (C), (D) AND (E): $\mathbf{P}=\mathbf{0 , 0 0}$

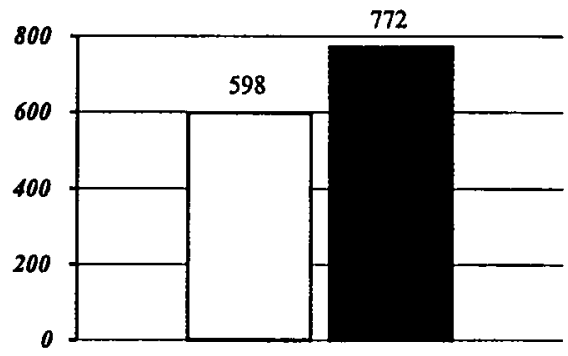

Whaben and other finite verbs Eparticiples

\section{Discussion:}

It is important to note here that, although I am comparing finite verbs with participles, the element sizes of the words in the two groups was controlled so that they could be kept compatible. The finite verbs had in average 1 syllable and 5 graphemes; the participles, 2 syllables and 7 graphemes. Thus, both groups varied from 1 to 2 syllables and from 5 to 7 graphemes, which meant an average difference between the two groups of 1 syllable and 2 graphemes.

Since the reaction times to the participles were significantly bigger (with an average of $772 \mathrm{~ms}$ ), compared to the reaction times to the finite verbs (598 ms average), I conclude that, upon reaching the participle, that is, at the end of the sentence, the volunteer has to reformulate his initial analysis, that considered the finite verb (haben) as main verb. The presence of a participle forces a reanalysis that delays the reaction time significantly, as we can see in Table 7. The result of this test is compatible to those found in the literature, such as in Frazier and Clifton Jr. (1996). It is the Garden path Effect, which lias as consequences the reanalysis and the possible repair of the frustrated predictions of Minimal Attachment, attested here. 
Test 2: Comparison among the reaction times to the complements and those to the participles - semantic plausibility effect of the internal argument

TABLE 8 - SENTENCES MODELS WITH VARIATION OF THE SEMANTIC PLAUSIBILITY LEVEL OF THE INTERNAL ARGUMENT. THE INTERNAL ARGUMENT SAMPLES WERE STATISTICALLY COMPARED AMONG THEMSELVES, AND THE PARTICIPLES SAMPLES TOO

\begin{tabular}{|c|c|c|c|c|}
\hline \multirow{3}{*}{$\begin{array}{c}\text { sentence } \\
\text { segments }\end{array}$} & Der Junge & hat & einen Saft $(\mathrm{F})$ & getrunken (I) \\
\cline { 2 - 5 } & Der Junge & hat & einen See (G) & gesehen (J) \\
\cline { 2 - 5 } & Der Junge & hat & einen Mond (H) & gezeichnet (K) \\
\hline
\end{tabular}

The mobilization impact in the semantic plausibility level of the complement was not statistically relevant in none of the two measured points: not after the complement nor after the participle.

The complements of type (F), Saft (juice), had a reaction time average of $638 \mathrm{~ms}$; those of type (G), See (lake), $690 \mathrm{~ms}$; and those of type (H), Mond (moon), $686 \mathrm{~ms}$. I compared the samples of $(F)$ with those of $(G)$ and found a $\mathbf{p}=\mathbf{0 , 4 1}$. The samples of $(F)$ with those of $(H)$ generated $p=0,46$; and those of $(G)$ with those of $(H), p=0,94$. Trough the comparison of all these segment samples, i. e., verbal complements that varied in semantic plausibility level, I obtained a $\mathrm{p}=0,65$.

TABLE 9 - SAMPLES OF (F), (G) AND (H) COMPARED AMONG THEMSELVES: $\mathbf{P = 0 , 6 5}$

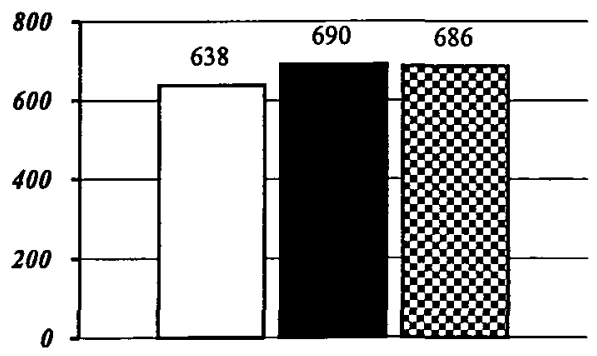

口Saft $\square$ See WMond 
The participles of type (I), getrunken (drunk), in sentences with +plausible object, had a $730 \mathrm{~ms}$ reaction time average; those of type (J), gesehen (seen), in sentences with \pm plausible object, $810 \mathrm{~ms}$ average; and those of type (K), gezeichnet (drawn), in sentences with -plausible object, average of $775 \mathrm{~ms}$. Comparing the reaction times of the three types of participle segments, in twos (three groups of two) and among the three types together, we see that the differences among them are not relevant. When I compared the reaction times to the participles of the type getrunken (I) with those of gesehen (J), I had $\mathbf{p}=\mathbf{0 , 1 6}$; those of getrunken (I) with those gezeichnet $(\mathrm{K}), \mathrm{p}=\mathbf{0 , 4 5}$; and those of gesehen (J) with those of gezeichnet $(\mathrm{K}), \mathbf{p}=\mathbf{0 , 6 1}$. By analyzing statistically all participle samples in sentences with variation of the semantic plausibility level of the internal argument, $(\mathrm{I}),(\mathrm{J})$ and $(\mathrm{K})$, the answer was $\mathbf{p}=\mathbf{0 , 4 3}$.

TABLE 10 - SAMPLES OF (I), ( () AND (K) COMPARED AMONG THEMSELVES: $P=0,43$

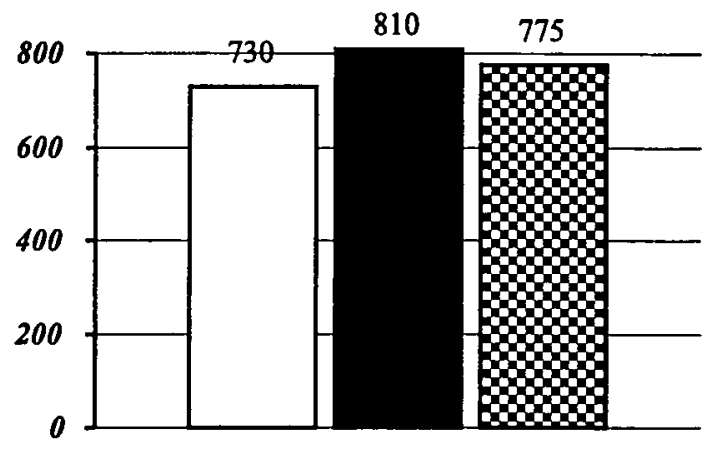

$\square$ getrunken $\mathbf{Q}$ gesehen $\square$ gezeichnet

\section{Discussion:}

Taking into account the Minimal Attachment predictions, already attested, the structure of the tested sentences in this series generates two possibilities of verb-complement merge: haben + complement and participle + complement.

In the first instance, the Minimal Attachment strategy exposes the volunteer to the three semantic plausibility levels when she integrates the object to the verb haben: for example, The boy has a juice, The boy has a lake, The boy has moon. 
But the reaction times to the internal argument did not present a bigger difficulty on the verb-complement merge, and that favors the interpretation that, at this moment, a merge was made without semantic access, i. e., according to the described terms by the Minimal Attachment strategy.

Following the derivation, coming across with the participle, the volunteer has to remake the merge, integrating the complement to the participle and, then, giving meaning to the sentence. I hoped that at this derivation point there would not be any statistically significant difference among the participles samples in sentences with semantic plausibility variation of the initial merge complement (with haben), because here the three semantic plausibility levels are neutralized, as the participles recover the sentence meaning, like in juice drank, lake saw and moon drew.

Statistically, I did not verify a difference among the reaction time to the complements on the three semantic plausibility levels studied. This means that semantic plausibility of the internal arguments is a factor that does not affect the sentence processing.

Test 3: Comparison among the participles reaction time - semantic plausibility effect of the external argument

TABLE 11 - SENTENCE MODELS WITH VARIATION OF THE SEMANTIC PLAUSIBILITY OF THE EXTERNAL ARGUMENT. THE PARTICIPLE SAMPLES WERE STATISTICALLY COMPARED AMONG THEMSELVES

\begin{tabular}{|c|c|c|c|c|}
\hline \multirow{2}{*}{$\begin{array}{c}\text { sentence } \\
\text { segments }\end{array}$} & Der Junge & hat & einen Saft & getrunken (L) \\
\cline { 2 - 5 } & Der Ameise & hat & einen Saft & gesehen (M) \\
\cline { 2 - 5 } & Der Stuhl & hat & einen Saft & gezeichnet (N) \\
\hline
\end{tabular}

Among all comparisons made in this test about the semantic plausibility effect of the external argument, the one that contrasts the participles of type (I), in sentences with +plausible subject, with those of type $(\mathrm{K})$, in sentences with -plausible subject, resulted in a statistically relevant difference among the samples of these two groups: $\mathbf{p}=\mathbf{0 , 0 1 6}$, i. e., only $1,6 \%$ probability of the samples being equal. Therefore, considering the statistical patterns that were used, I can 
affirm that the $871 \mathrm{~ms}$ average of the participles in sentences with -plausible subject, of the type chair (Stuhl), is effectively bigger than the $730 \mathrm{~ms}$ average of the participles with +plausible subject, of the type boy (Junge).

TABLE 12 - SAMPLES OF (L) AND (N) COMPARED AMONG THEMSELVES: $\mathbf{P = 0 , 0 1 6}$

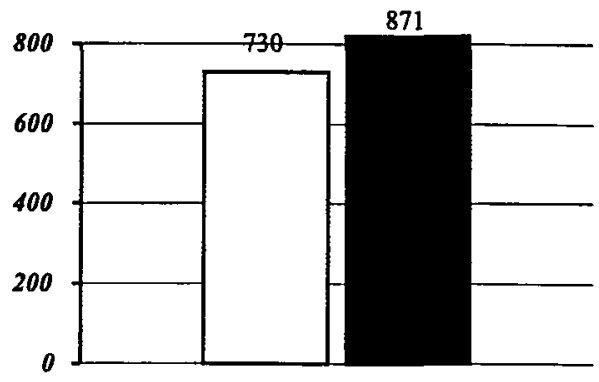

$\square$ (der Junge) getrunken $\mathbf{E}$ (der Stuhl) getrunken

Discussion:

Taking into consideration that when I tested the external argument, I always kept the internal argument at a plausible level, the delayed reaction time after the participle in sentences whose external argument was less plausible reveals that the volunteers had more difficulty integrating the new material (the participle) to the structure that was already formed. The effect of 'semantic plausibility' shows that the speaker tried to attribute new sense to the sentence, when she had to reconsider haben as an auxiliary verb and had to deal with the task of uniting the subject to the auxiliary-complement-verb set.

This finding of a delayed reaction time during the reanalysis, that will finally integrate the participle, indicates that the merge conception is really bottom-up, according to Miller and Chomsky (1963) and Chomsky (1995). It is in the merge between the verb and its complement that the Primary Syntactic Relations happen, as described in Frazier and Clifton Jr. (1996) through the measurement of the volunteer's reaction time to sentence segments. In Friederici (2002), this process is identified between the initial 40 and $100 \mathrm{~ms}$, by the volunteer's electro-cortical answer to the linguistic stimulus.

The subject-verb relation is not a Primary Syntactic Relation. The thesis here is that the subject requires an initial phase of storage in the memory, possibly with a minimum semantic access, so that it can be then merged to the verb-object set. 
LAGE, A. C. Syntactic and semantic access in German...

\section{Conclusion}

The presented findings confirmed in German two basic Sentence Processing hypotheses: the Minimal Attachment and the Garden path Effect.

According to the reaction time to the phrasal segments, I believe that volunteers processed the sentences first through the Minimal Attachment strategy, merging the finite verb to the complement, i. e., establishing the Primary Syntactic Relations of subcategorization. The fact that haben, as auxiliary or lexical finite verb, and the other verbs in finite form yielded similar processing times revealed that, in this stage, the volunteers did not access the semantic content of the phrasal elements.

Thus, regarding the complements, the variable 'semantic plausibility level' did not produce any effect, even among the perfectly acceptable and the completely absurd ones. Therefore, the semantic nature of these constituents did not interfere in the syntactic operations and, consequently, did not increase the sentence processing time.

When the Minimal Attachment strategy fails, the speaker fulfills a reanalysis and a repair of the structure, attempting to understand the sentence. It is exactly at this moment that there is access to the constituents on the semantic level. When the volunteers arrived to the last sentence segment and still had to deal with a participial verb, they got into a Garden path, reanalyzed the sentence and tried to repair it, to give it a sense. The repair event appeared in the test through the fact that the processing times to the participle were significantly longer than those to haben. In reality, the reaction time to the participle is related not only to its processing, but also to the Garden path Effect, the reanalysis and the repair of the whole sentence, verified in the stimuli of these experiment tests: in the test with manipulation of the complement and in the other with manipulation of the subject.

But the impressing result was that of the third test, which manipulated the semantic plausibility of the external argument. The reaction time to the participle was significantly longer in sentences with semantically less plausible external arguments, i. e., the most absurd subjects. This fact can be indicative of two phenomena. Firstly, volunteers seemed to have been sensitive to the semantic plausibility of external argument. Despite coming linearly before the internal argument, the external argument is not integrated into the derivation immediately. It seems to be stored in the memory, and only after that, is it merged to the verbcomplement set. This strategy of keeping the subject in the memory to be merged 
later certainly demands some initial semantic access, but initially it is not integrative.

Secondly, if the semantic plausibility effect only takes place after the participle is integrated this seems to indicate that the external argument is certainly merged after the verb-complement set, a finding that brings psychological evidence to confirm the bottom-up hypothesis, postulated in Miller and Chomsky (1963) and Chomsky (1995).

\section{ABSTRACT}

An on-line psycholinguistic experiment was created to test the Minimal Attachment and the Garden path Effect in German, assuming the processing account in Frazier and Clifton Jr. (1996). An S-Aux-O-V structure would be read, in an initial hypothesis, considering the auxiliary as a main verb and merging the complement immediately to it. This happens until the participial form of the verb appears, which causes the Garden path Effect, a reanalysis and possibly a repair of the sentence as a whole. The speaker reinterprets the initially supposed main verb as an auxiliary and then merges the complement to the genuine main verb. The semantic access of the internal and external arguments was also investigated, by testing the semantic plausibility interference of both constituents in the processing timeline. We verified the speaker's sensitivity to the semantic plausibility effect of the external argument, but not to that of the internal argument. This fact indicates that there might be some kind of semantic access to the external argument in the initial stage of sentence processing. The external argument affects the reaction time to the last processed segment, according to its semantic plausibility. This brings experimental evidence of bottom-up processing (Miller; Chomsky, 1963; Chomsky, 1995).

Key-words: on-line psycholinguistic experiment, minimal attachment, internal and external arguments.

\section{RESUMO}

Foi criado um experimento psicolingüístico on-line para testar o Minimal Attachment e o Efeito Garden path em alemão, utilizando o modelo Construal de processamento de sentença, em Frazier e Clifton Jr. (1996). Uma estrutura S-Aux-O-V seria lida, em uma hipótese inicial, considerando-se o verbo auxiliar como principal e concatenando-se o complemento imediatamente a ele. Isto acontece até que apareça a 
LAGE, A. C. Syntactic and semantic access in German...

forma participial do verbo, que causa o Efeito Garden path, uma reanálise e uma possível reparação da sentença como um todo. $O$ falante reinterpreta $o$ inicialmente suposto verbo principal como um auxiliar e então concatena o complemento ao genuíno verbo principal. $\mathrm{O}$ acesso semântico dos argumentos interno e externo também foi investigado, ao se testar a interferência da plausibilidade semântica de ambos os constituintes no tempo de processamento. Verificou-se a sensibilidade do falante ao efeito da plausibilidade do argumento externo, mas não ao do argumento interno. Este fato indica que deve haver algum tipo de acesso semântico ao argumento externo no estágio inicial do processamento da sentença. $O$ argumento externo afeta o tempo de reação do último segmento processado, de acordo com sua plausibilidade semântica. Isto caracteriza uma evidência experimental quanto ao processamento bottom-up, em Miller e Chomsky (1963) e Chomsky (1995).

Palavras-chave: experimento psicolingüístico on-line, minimal attachment, argumentos interno e externo.

\section{REFERENCES}

CHOMSKY, Noam. Beyond explanatory adequacy. MIT Occasional Papers in Linguistics, Cambridge, n. 20, 2001.

. Derivation by phase. MIT Occasional Papers in Linguistics, Cambridge, n. 18, 1999. The minimalist program. Cambridge, Massachusetts: The MIT Press, 1995.

FRAZIER, Lyn; CLIFTON JUNIOR, Charles. Construal. Cambridge, Massachusetts: The MIT Press, A Bradford Book, 1996.

FRIEDERICI, Angela D. Towards a neural basis of auditory sentence processing. Trends in Cognitive Sciences, New York, v. 6, n. 2, p. 78-84, 2002.

MILLER, George A.; CHOMSKY, Noam. Finitary Models of Language Users. In: LUCE, Duncan R.; BUSH, Robert R.; GALANTER, Eugene (Eds.). Handbook of mathematical psychology. New York: Wiley, 1963. v. 2, p. 419-493. 